\title{
Keep your eye on the ball!
}

\section{Catherine Maumi}

\section{(Q) OpenEdition}

Journals

Édition électronique

URL : http://journals.openedition.org/crau/491

DOI : 10.4000/crau.491

ISSN : 2547-5746

\section{Éditeur}

Éditions du patrimoine

\section{Édition imprimée}

Date de publication : 1 septembre 2013

Pagination : 12-24

ISBN : 978-2-7577-0109-6

ISSN : $1296-4077$

Référence électronique

Catherine Maumi, « Keep your eye on the ball! », Les Cahiers de la recherche architecturale et urbaine [En ligne], 28 | 2013, mis en ligne le 12 septembre 2017, consulté le 03 mai 2019. URL : http:// journals.openedition.org/crau/491; DOI : 10.4000/crau.491 


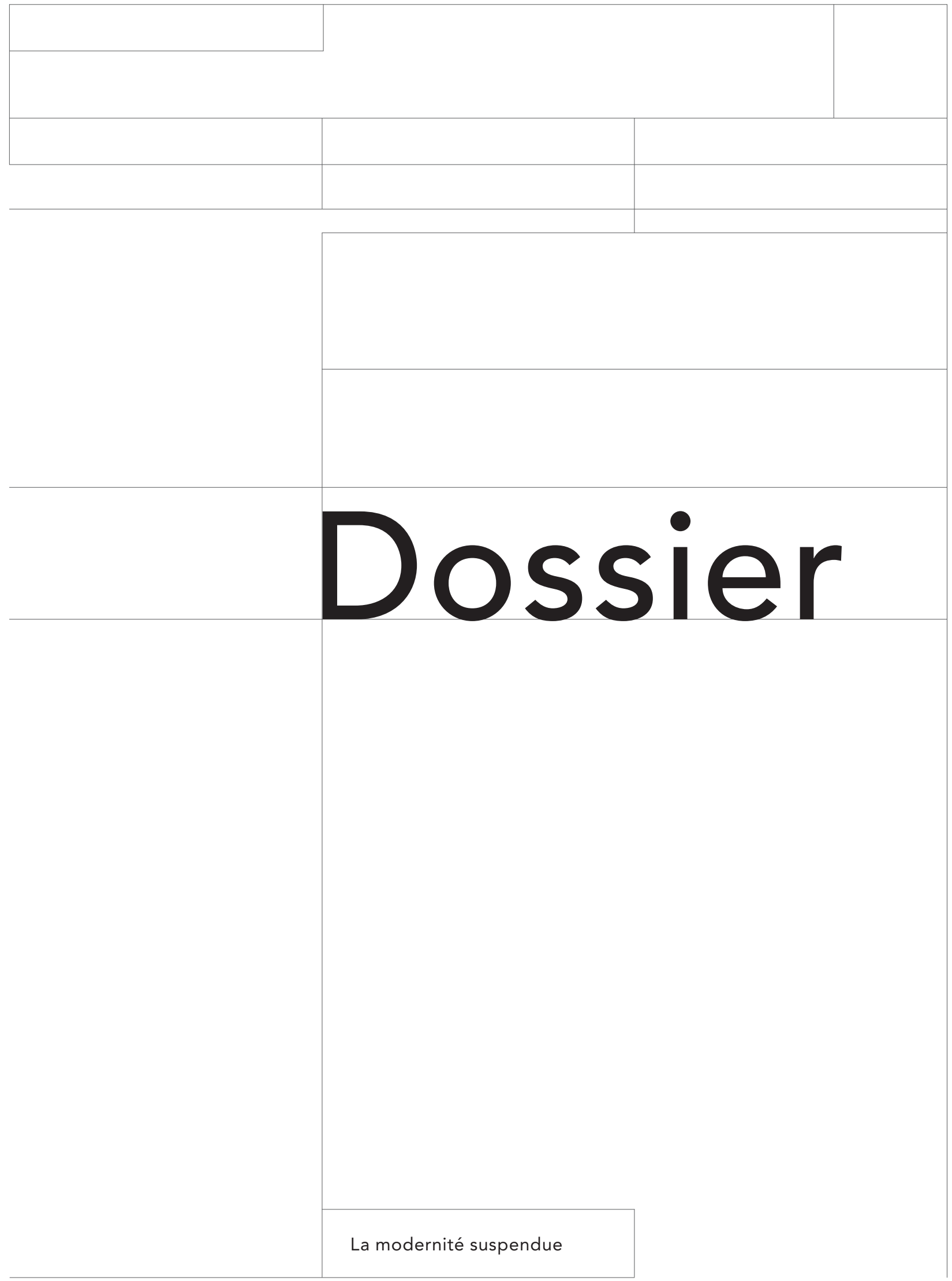


